\title{
Bevacizumab 硝子体内注射による血管新生緑内障の新生血管への影響
}

\author{
石橋 真吾*，近藤 寛之
}

産業医科大学 医学部 眼科学教室

要旨：血管新生緑内障は, 網膜の虚血性変化により血管内皮増殖因子(vascular endothelial growth factor; VEGF) が産生され, 虹彩や前房隅角に新生血管が形成されると考えられている. 血管新生緑内障に, 抗VEGF抗体で ある bevacizumabを硝子体内注射すると, 細隙灯顕微鏡検査で虹彩や前房隅角の新生血管が消退すると報告されてい る.しかし, 蛍光前眼部造影検査を用いて観察すると, bevacizumabは, 新生血管そのものを消退させるのではなく, 新生血管の透過性を減少させることが分かった。本総説では, 血管新生緑内障の病態と診断, bevacizumab 硝子体内 注射による虹彩と前房隅角の新生血管に及ぼす影響について詳述する。

キーワード : 血管新生緑内障, bevacizumab, 硝子体内注射, 血管透過性.

（2015年 10 月 5 日 受付, 2015 年 11 月 5 日 受理)

\section{は じめに}

血管新生緑内障は, 虹彩および前房隅角の血管新生 に続発する難治性の緑内障である。網膜の虚血性変化 により血管内皮増殖因子 (VEGF) が産生され, 硝子体 中や房水中のVEGF の濃度が増加し, 虹彩や前房隅角 に新生血管が形成される.

最近, 血管新生緑内障に対して, 抗VEGF抗体である bevacizumab硝子体内注射が行われ, bevacizumab 硝子 体内注射後早期に, 細隙灯顕微鏡で虹彩や前房隅角の 新生血管の退縮が観察されるとともに, 眼圧が下降す ると報告されている $[1]$.

本総説では, 血管新生緑内障の病態と診断, bevacizumab硝子体内注射による虹彩と前房隅角の新生血管 に及ぼす影響について詳述する。

\section{血管新生緑内障の病態}

血管新生緑内障は, 糖尿病網膜症, 網膜中心静脈閉塞 症などの網膜を含む眼球の虚血性変化が原因で, 網膜 グリア細胞や網膜色素上皮細胞などから,さまざまな
血管新生増殖因子が分泌され, 虹彩および前房隅角に 新生血管が生じると考えられている $[2,3]$ ，血管新生 増殖因子には, 血管内皮増殖因子(VEGF), インスリン 様増殖因子, 塩基性線維芽細胞増殖因子などの細胞増 殖因子やインターロイキンなどがあり，そのなかでも もっとも重要なのは, VEGFである $[4]$. 増殖糖尿病網 膜症による虹彩新生血管を有する眼の前房水のVEGF 濃度が上昇していることが, 1994年に初めて報告され ている [4].

血管新生緑内障の病期は臨床所見および隅角所見か ら 3 期に分けられ, 1 期の血管新生期, 2 期の開放隅角緑 内障期, 3 期の閉塞隅角緑内障期の順に進行する [5]. 1 期は, 虹彩や前房隅角に新生血管が生じていないが, 眼圧上昇をきたしていない時期である。2期は，隅角 は開放隅角であるが, 虹彩や前房隅角に形成された新 生血管のために, 眼圧が上昇している時期である. 3 期は, 病期がさらに進行し, 周辺虹彩前癒着が起こって 隅角が閉塞する時期である。眼圧上昇は不可逆性とな る. ヒトの開放隅角緑内障期の血管新生緑内障眼を光 学顕微鏡, 電子顕微鏡, さらに血管内皮細胞のマーカー である抗CD34モノクローナル抗体を用いた免疫組織

*対応著者: 石橋 真吾, 産業医科大学 医学部 眼科学教室, † 807-8555, 北九州市八幡西区医生ヶ丘 1-1, Tel: 093-691-7261, Fax: 093603-3657, E-mail: ganka-gaku@ mbox.med.uoeh-u.ac.jp 
化学染色で観察すると, 線維柱带の線維柱間隙には新 生血管が侵入している $[6]$. 現在, この時期の眼圧上昇 機序として,2つ考えられている。1つは, 隅角線維柱 带の線維柱間隙に新生血管が侵入するために房水の流 出が妨げられている説 [7], あるいは, 新生血管の内皮 細胞には空構造(fenestration)があり, 血液成分が房水 中に漏出するために房水の流出抵抗が増加する説があ るが[8],いまだ明らかではない.

\section{血管新生緑内障の診断}

血管新生緑内障の診断は, 虹彩や前房隅角に形成さ れた新生血管を見つけることである (Fig. 1) [9]．血管 新生緑内障の病期 1,2 期では, 細隙灯顕微鏡検査や隅
角鏡を用いて注意深く観察を行っても, 虹彩や前房隅 角の新生血管が微小なため発見が困難なことがある. その場合, 虹彩や前房隅角の新生血管の検出には, 蛍光 前眼部造影検査が有用である [10]. 虹彩の造影検査 で,インドシアニングリーンを用いた造影検査では, 虹 彩の新生血管から蛍光漏出はなく, 虹彩の血管構造が 観察される。フルオレセインを用いた造影検査では, 虹彩の新生血管から旺盛な蛍光漏出がみられる。前房 隅角の造影検査で, インドシアニングリーンを用いた 造影検査では, 蛍光漏出はなく, 線維柱带に血管網が観 察される。フルオレセインを用いた造影検査では, 血 管網から蛍光漏出が带状の過蛍光として観察される $[10,11]$.
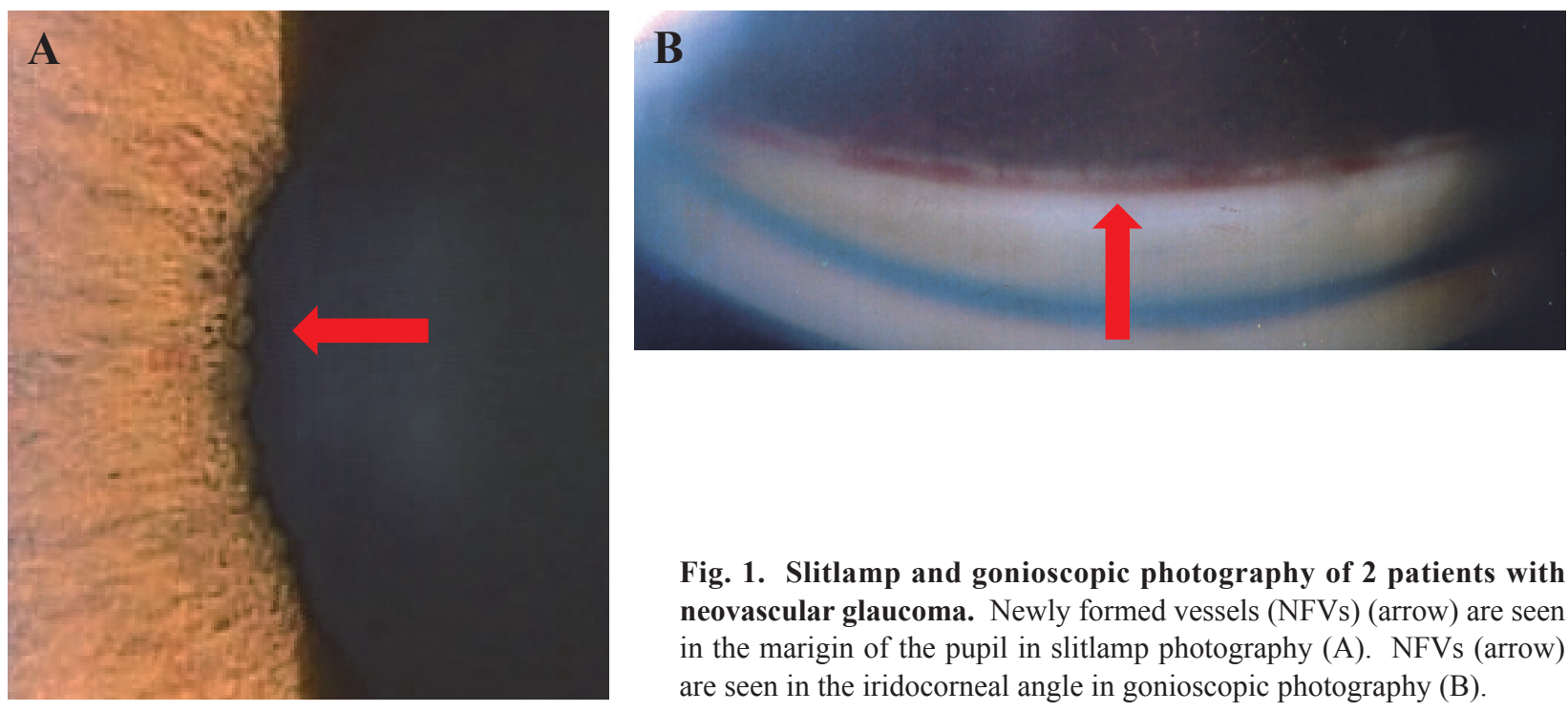

Bevacizumab硝子体内注射による虹彩と前房隅角の 新生血管に及ぼす影響

2006年から血管新生緑内障に対する bevacizumab硝 子体内注射の有効性が多く報告されている $[1,8,12$, 13]. 血管新生緑内障に対して, 抗VEGF抗体である bevacizumab 硝子体内注射が行われ, bevacizumab硝子 体内注射の効果は一時的であるが, 細隙灯顕微鏡で虹 彩や前房隅角の新生血管が消退し, 眼圧が下降する.

著者らは, bevacizumab硝子体内注射による虹彩や前 房隅角の新生血管に及ぼす影響について, 蛍光前眼部 造影検査を用いて調べた [11]。その結果, これまでの 報告と同様に, bevacizumab 硝子体内注射(投与量 1.25 $\mathrm{mg}$ )の前に細隙灯顕微鏡でみられた虹彩および前房隅 角の新生血管は, bevacizumab 硝子体内注射 4 日から 6 日後には, 観察されなくなった。しかし,インドシアニ ングリーンを用いた造影検查(IA)では, bevacizumab硝 子体内注射前後で虹彩や前房隅角の血管分布のパター ンに変化はみられなかった。フルオレセインを用いた 造影検查(FA) では, bevacizumab硝子体内注射の前に 虹彩や前房隅角の新生血管から旺盛な蛍光漏出がみら れたが, 注射後新生血管からの漏出は著明に減少した (Fig. 2, 3). 新生血管は空構造を有しており,フルオレ セインはこの空を通過できるがインドシアニングリー ンは通過できない，そのため, IA は血管の構築の観察 に有用で, FAによる造影検查は新生血管の内皮細胞に 
ある空構造の状態を知るのに有用である。このことか ら, bevacizumab 硝子体内注射で新生血管を消失させる のではなく, 空構造が減少することが示唆された.

血管新生緑内障眼に対する bevacizumab 硝子体内注 射後の線維柱带組織を光学顕微鏡, 電子顕微鏡および 抗CD34モノクローナル抗体を用いた免疫組織化学染 色で観察した報告では [14], bevacizumab 硝子体内注射 の有無にかかわらず, 線維柱带に新生血管が存在して いたが, 注射をすると注射していない例と比較して, 新 生血管の空構造の数は減少していた。 また, サル眼に bevacizumab 硝子体内注射を行うと, 脈絡膜毛細血管板
の内皮細胞の空構造が減少するとの報告がある $[15]$.

これらのことから, bevacizumab硝子体内注射に よって, 虹彩や前房隅角の新生血管の分布に変化は ないが, 空構造が減少して新生血管の透過性が減少す ることが示唆される。 また，血管新生緑内障に対す る bevacizumab硝子体内注射の眼圧下降機序として, bevacizumabにより線維柱带に血管構造が残存するが, 血管の透過性が減少することで新生血管から房水中へ 血漿成分の流出が妨げられるため, 房水流出抵抗が軽 減し, 眼圧下降が得られると考えられる。

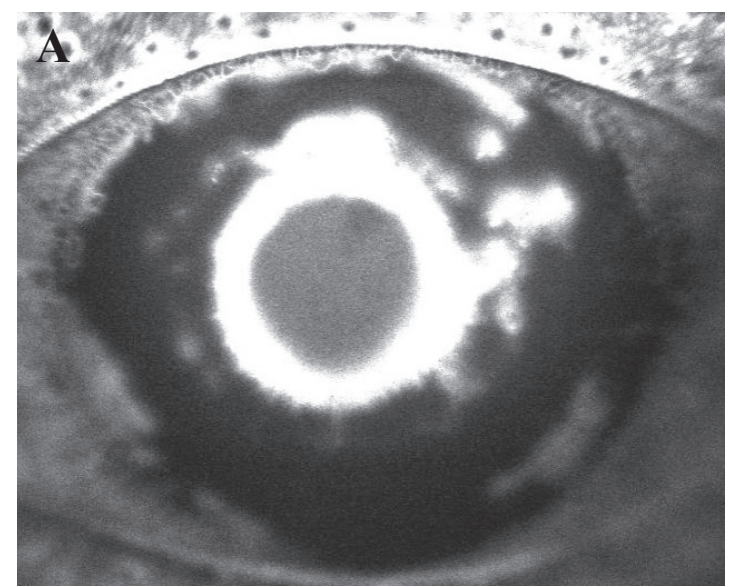

FA

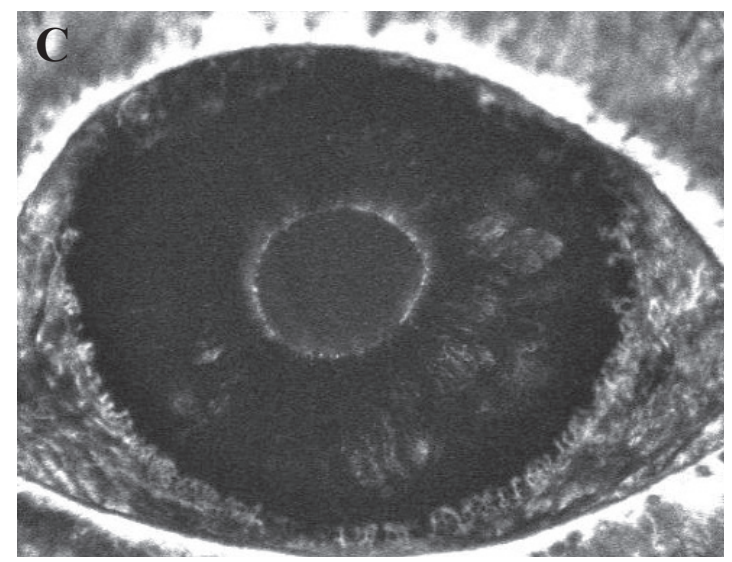

FA

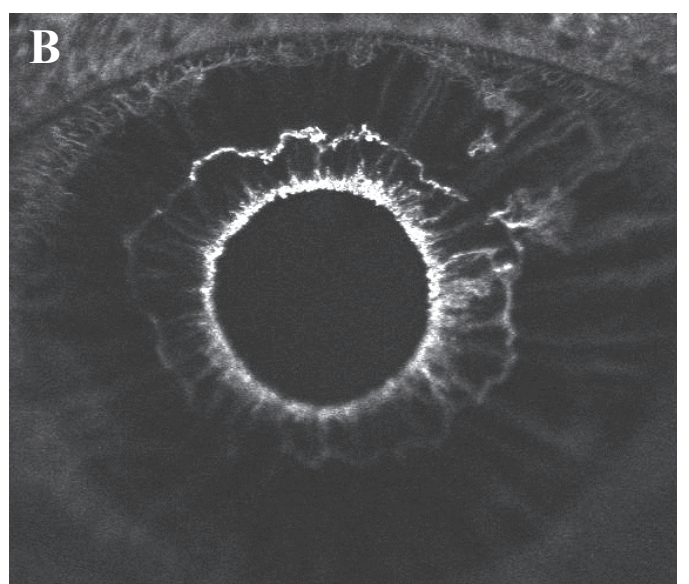

IA

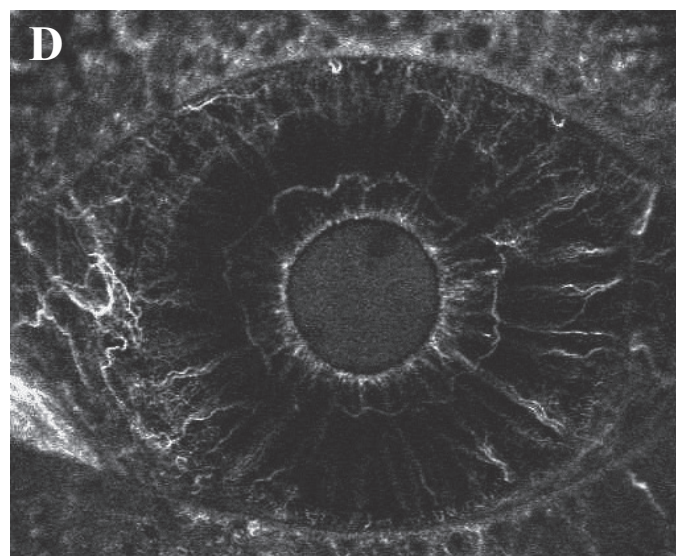

IA

Fig. 2. Fluorescein (FA) and indocyanine green angiography (IA) of the iris in an eye with neovascular glaucoma. At 55 seconds before intravitreal injection of bevacizumab, FA shows remarkable leakage from the newly formed vessels (NFVs) at the papillary margin and the surface of the iris (A), whereas IA shows no leakage from NFVs despite revealing their structure (B). At 106 seconds after bevacizumab treatment in the same eye, FA shows less dye leakage from NFVs compared with pretreatment (C), whereas IA shows no change in the images and structures of NFVs (D). 


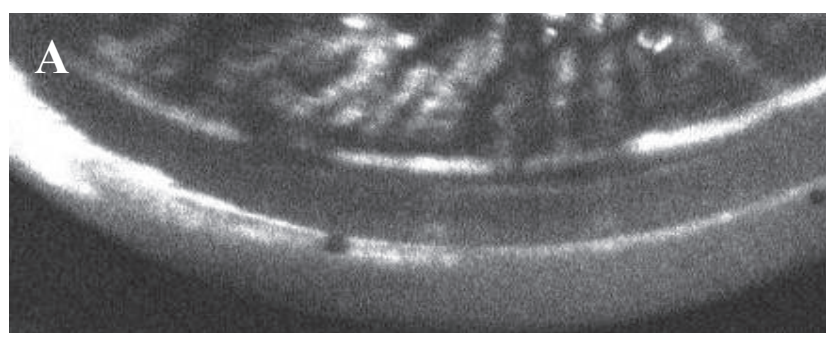

FA

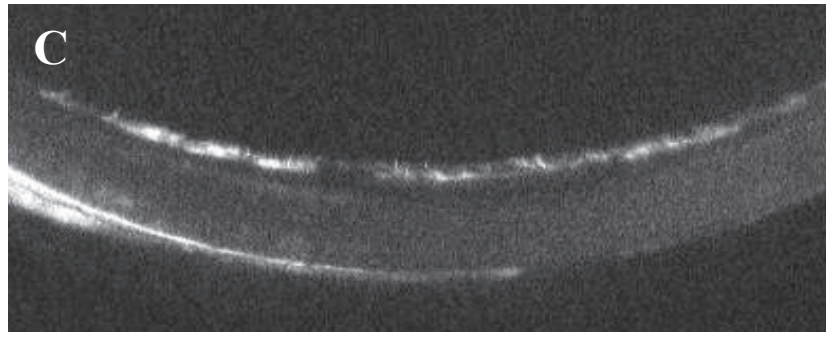

FA

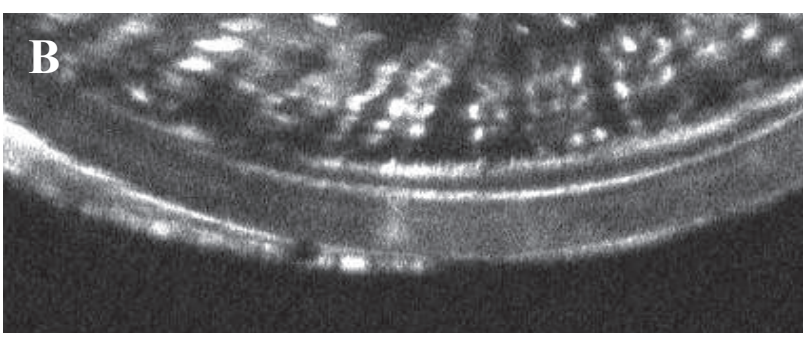

IA

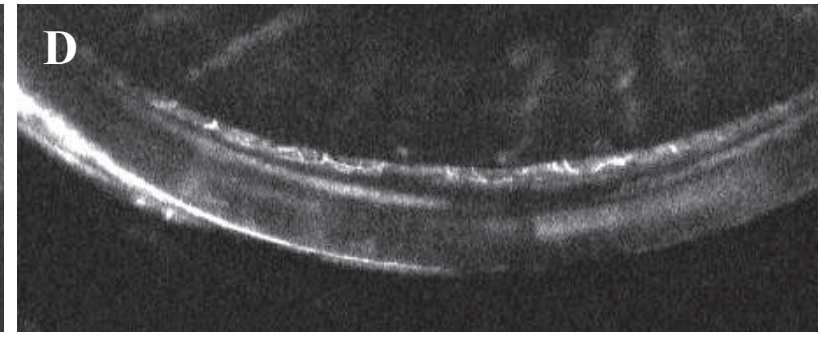

IA

Fig. 3. Fluorescein (FA) and indocyanine green angiography (IA) of the iridocorneal angle in an eye with neovascular glaucoma. At 40 seconds before intravitreal injection of bevacizumab, FA shows a bright zonal structure with leakage from newly formed vessels (NFVs) (A), and IA shows the structure of the neovascular network (B). At 40 seconds after bevacizumab treatment in the same eye, FA shows less dye leakage from NFVs compared with pretreatment (C), whereas IA shows no change in the images and structures of the neovascular network (D).

$$
\text { ま と め }
$$

血管新生緑内障の病態を正確に把握することは, 血 管新生緑内障患者に有益であり, 社会的失明の予防に 役立つものと思われる. 今後, VEGF以外の分子を標 的とした抗血管新生薬の開発や血管新生緑内障の眼圧 上昇機序の解明に基づく新たな緑内障治療薬の開発が 望まれる。

\section{利益相 反}

利益相反に相当する事項はない.

\section{引用文 献}

1. Wakabayashi T, Oshima Y, Sakaguchi H, Ikuno Y, Miki A, Gomi F, Otori Y, Kamei M, Kusaka S \& Tano Y (2008): Intravitreal bevacizumab to treat iris neovascularization and neovascular glaucoma secondary to ischemic retinal diseases in 41 consecutive cases. Ophthalmology 115 : $1571-1580$
2. 田原昭彦 (2009): 血管新生緑内障の治療戦略. 臨 床眼科 $63(11): 351-355$

3. 田原昭彦 (2010) : 緑内障と前房隅角. 第20回緑 内障学会 須田記念講演. あたらしい眼科 27 : 1067-1076

4. Aiello LP, Avery RL, Arrigg PG et al (1994): Vascular endothelial growth factor in ocular fluid of patients with diabetic retinopathy and other retinal disorders. N Engl J Med 331: 1480-1487

5. 田原昭彦, 久保田敏昭, 坂本泰二, 他 (1999)：血管 新生緑内障の発症メカニズム-血管新生緑内障の 発生病理-。眼科手術 12: 117-120

6. Kubota T, Tawara A, Hata Y, Khalil A \& Inomata H (1996): Neovascular tissue in the intertrabecular spaces in eyes with neovascular glaucoma. Br J Ophthalmol 80: $750-754$

7. 猪俣 孟, 石橋達朗, 村田敏規, 岩崎雅行 (1993): 糖 尿病と眼一形態学的にみた糖尿病眼合併症 - . 細 胞 25: 180-184

8. Avery RL (2006): Regression of retinal and iris neovascularization after intravitreal bevacizumab (Avas- 
tin) treatment. Retina 26: 352-354

9. 石橋真吾 $(2013): 5$. 血管新生緑内障. 病態と診断. 糖尿病眼合併症の新展開. 専門医のための眼科 診療クオリファイ. 16巻. (白神史雄 編) 中山 書店, 東京 pp 194-198

10. 川崎貴子, 後藤美和子, 久保田敏昭, 田原昭彦, 大 西克尚, 猪俣 孟(1997): 走査レーザー検眼鏡を用 いた前眼部新生血管の蛍光造影検査. 臨床眼科 51: 999-1001

11. Ishibashi S, Tawara A, Sohma R, Kubota T \& Toh N (2010): Angiographic changes in iris and iridocorneal angle neovascularization after intravitreal bevacizumab injection. Arch Ophthalmol 128: 1539-1545

12. Avery RL, Pearlman J, Pieramici DJ, Rabena MD, Castellarin AA, Nasir MA, Giust MJ, Wendel R \&
Patel A (2006): Intravitreal bevacizumab (Avastin) in the treatment of proliferative diabetic retinopathy. Ophthalmology 113: 1695-1705

13. Yazdani S, Hendi K \& Pakravan M (2007): Intravitreal bevacizumab (Avastin) injection for neovascular glaucoma. J Glaucoma 16: 437-439

14. Kubota T, Aoki R, Harada Y, Tou N, Kohno Y, Tawara A, Satoh H \& Shimajiri S (2009): Trabecular meshwork in neovascular glaucoma eyes after the intravitreal injection of bevacizumab. Br J Ophthalmol 93: 557-558

15. Peters S, Heiduschka P, Julien S, Ziemssen F, Fietz H, Bartz-Schmidt KU, Tubingen Bevacizumab Study Group \& Schraermeyer U (2007): Ultrastructural findings in the primate eye after intravitreal injection of bevacizumab. Am J Ophthalmol 143: 995-1002 
Effect of Intravitreal Bevacizumab Injection on Iris and Iridocorneal Angle Neovascularization in Neovascular Glaucoma

\author{
Shingo IsHiBASHI and Hiroyuki Kondo
}

Department of Ophthalmology, School of Medicine, University of Occupational and Environmental Health, Japan. Yahatanishi-ku, Kitakyushu 807-8555, Japan

\begin{abstract}
Neovascular glaucoma is a serious complication associated with retinal ischemic changes, which increase the production of vascular endothelial growth factor. Vascular endothelial growth factor has been implicated as a key molecule in the development of newly formed vessels and neovascular glaucoma. Intravitreal injection of bevacizumab, a full-length humanized anti-vascular endothelial growth factor monoclonal antibody, leads to a dramatic regression of the new iris and iridocorneal angle vessels on slitlamp examination. However, anterior segment angiography reveals that bevacizumab does not cause a regression of the neovascular vessels themselves but reduces vascular permeability while newly formed vessels are still present in the iris and iridocorneal angle. This review focuses on the pathology and diagnosis of neovascula glaucoma and the effect of intravitreal bevacizumab on the iris and iridocorneal angle neovascularization.
\end{abstract}

Key words: neovascular glaucoma, bevacizumab, intravitreal injection, vascular permeability.

J UOEH $37(4): 299-304(2015)$ 